proved compatible with a curious and unexpected process of social desecularization, a revival of puritanical religiosity and (presumably) a reinvigoration of religious associations. The Protestant ethic and the spirit of capitalism have joined forces again, and in coalition seem ambitious to rule the world.

Michael Lessnoff

University of Glasgow, UK.

\title{
Reclaiming the Enlightenment: Toward a Politics of Radical Engagement
}

Stephen Eric Bronner

Columbia University Press, New York, 2004, 167pp.

ISBN: 0231126085.

Contemporary Political Theory (2006) 5, 93-95. doi:10.1057/palgrave.cpt.9300214

Here Stephen Bronner sets himself the task of recovering a politics defined by justice and practical engagement. A first step towards this is to discredit Adorno and Horkheimer's claim that the Enlightenment ideal of the 18th century philosophes was doomed to conclude in 'barbarism, Auschwitz and ... "the totally administered society" (pp. 3, 110). Dismissing this as selfindulgent 'cultural pessimism,' Bronner insists that far from leading us to barbarism, the Enlightenment remains a living project to which we must return if we are to stave off those neo-conservatives and religious fundamentalists currently undermining the ideals of 'autonomy, tolerance and reason' (pp. xi, 2). But Bronner is not just concerned with the false turns of the early Frankfurt School or the iniquities of the contemporary right. Indeed, his (p. 17) more fundamental purpose is to challenge that 'motley crew' of deluded leftists who, in the guise of post-structuralists, communitarians, and multiculturalists, unwittingly embrace the reactionism of the historical Counter-Enlightenment and all that it entailed: privilege, tradition, particularity, myth and, ultimately, cruelty. Bronner's aim, therefore, is both to lash the contemporary left for its attachment to fashionable fallacies and to realign it towards a socially conscious liberalism, the fulfilment of Kant's maxim, Sapere Aude!

The scope of this re-alignment is ambitious, demanding a comprehensive rehabilitation of Enlightenment philosophy, science, and politics. As to Enlightenment philosophy, its best practitioners, Voltaire as much as Locke and Kant, were motivated not by abstract rationalism but a 'pragmatic idealism' concerned to change the world through 'critical reflection on society, its traditions, its ideologies, and its institutions' (pp. 7, 73). The ideal of transparency underlining this egalitarian philosophy and its key institution, the 
bourgeois public sphere, stands worlds apart from the deliberately obscurantist musings of Adorno and Horkheimer, which substituted an aesthetic retreat into inner 'subjectivity' and impotent metaphysics for solidarity with the oppressed and concrete critical reflection (pp. 121-125). Having no place for 'mediations or qualifications' and blind to the gulf between the philosophes and their reactionary enemies during the 18th and 19th centuries, it is unsurprising that Adorno and Horkheimer would equate the Enlightenment legacy with the loss of individual autonomy, the growth of a dominative impersonal science, and the rise of totalitarianism (p. 113).

But neither the thought of the enlightened philosophes nor the historical record bears this equation out. Enlightenment science was and remains inherently liberatory, its criteria of falsification indispensable for adequate perception of the external world and its underlying assumption of 'progress' having no necessary connection with dominion over man or nature, as is attested to by the non-reductionist philosophy of nature developed by Ernst Bloch, which is 'less a rejection than a logical outgrowth of Enlightenment thought' (p. 161). As to the charge of totalitarianism, right-wing totalitarian regimes owed their genesis to the historical Counter-Enlightenment's stress on blood and community, whereas those of the left sprang from a voluntarist conception of politics wholly alien to clear-headed reformers such as Montesquieu or Madison and drawing instead from the romanticism of Novalis and the young Marx, their 'anti-political' and 'apocalyptic' yearning for re-enchantment and non-alienation (pp. 108, 153). Thus, totalitarianism issued from no Enlightenment 'dialectic,' but from movements which defined themselves in opposition to the reformist, laudably realistic spirit of the philosophes. From the start, this spirit concerned itself with the worldly conditions of individual autonomy, the most basic being civil liberty, accountable power, and social justice. And it is because these conditions are still unrealized today that Bronner urges unambiguous commitment to internationalizing human rights and patterns of just economic distribution. A liberal social democracy underpinned by compassion and 'cosmopolitan sensibility' is, in short, the sole viable alternative to irresponsible withdrawalism or smug complacency.

There is much to Bronner's polemic. Although nothing new to readers of Habermasian critical theory, Bronner's argument against 'totalizing critiques' is fundamentally sound, as is his insistence on the historical connection between the philosophes and emancipatory movements such as socialism, feminism, and anti-imperialism. Similarly, his dogged focus on political institutions and the social relations constraining freedom and solidarity is a welcome relief from the oftentimes esoteric deconstructions offered by poststructuralists, as well as those abstract systematizations favoured by many Anglo-American egalitarians. There is much political wisdom here, too, in 
particular his defence of the modern state as an institution indispensable to individual freedom and social justice (pp. 151-152). Yet Reclaiming the Enlightenment is disappointing for two reasons, the first concerning Bronner's overly enthusiastic rehabilitation of the Enlightenment, the second his arguable enervation of its radical heritage. While certainly cognizant of the link between Enlightenment thought and modern capitalism, and calling for a decisive break with classical liberalism, Bronner fails to excavate that link in sufficient depth and thus suppresses the invidious role 'contract' and other liberal ideals played in justifying, for instance, the brutal expropriation of indigenous peoples in the New World and the lower classes in the Old. The same, too, with his overly sanguine reading of 'progress,' which, as he admits (p. 24), proved a key ideological prop to imperialism and the excesses of modern science. Bronner's claim that this represented a perversion of Enlightenment ideals hardly suffices, for the same can surely be said of crimes committed in the name of the great religions, which he condemns in the harshest of tones. Thus, although Bronner properly lambastes the one-sidedness of Adorno and Horkheimer, zealousness leads him to a narrative that is almost the mirror image of theirs, an Enlightenment that is questionable precisely because of its shining rectitude. Moreover, his Enlightenment is self-consciously reformist, content with liberal constitutionalism and at odds with the utopianism of the young Marx. Yet in important respects this utopianism expresses the fundamental spirit of Enlightenment thought, the promise and realization of 'human' emancipation. Such, at least, was the view of Bloch, whose work Bronner praises, but which was explicitly conceived in terms of the early Marx's 'left Aristotelianism.' Thus, not only does Reclaiming the Enlightenment offer a largely sanitized vision of the Enlightenment, but that vision fails to capture the radical import of Enlightenment thinking.

Keith Breen

Queen's University Belfast, UK.

\author{
Feminist Political Theory: An Introduction (2nd edn) \\ Valerie Bryson \\ Palgrave Macmillan, Basingstoke \& New York, 2003, ix +281pp. \\ ISBN: 0333945689.
}

Contemporary Political Theory (2006) 5, 95-97. doi:10.1057/palgrave.cpt.9300216

In this expanded second edition Valerie Bryson charts the development of Western feminist thought from the emergence of the first recognizable feminist 